\title{
Approximation Of The Benefits Of Socioeconomic Activities In Cocos Island National Park And The Effects Of Climate Change
}

\section{Aproximación de los beneficios de las actividades socioeconómicas en el parque nacional isla del coco (PNIC) y efectos del cambio climático}

\section{Mary Luz Moreno', Keylin Jiménez ${ }^{2}$, Cristina Villalobos ${ }^{3}$}

$1 \mathrm{PhD}$ in Natural Sciences for Development with an emphasis on Natural Resource Management. Academic and researcher at the Centro Internacional de Política Económica para el Desarrollo Sostenible (International Center for Economic Policy for Sustainable Development). Universidad Nacional. Heredia, Costa Rica.

2 Master's student in Economic Policy with an emphasis on Sustainable Development. Research assistant, Centro Internacional de Política Económica para el Desarrollo Sostenible (International Center for Economic Policy for Sustainable Development). Universidad Nacional. Heredia, Costa Rica.

3 Master in Economic Policy with an emphasis on International Economics. Researcher at the Centro Internacional de Política Económica para el Desarrollo Sostenible (International Center for Economic Policy for Sustainable Development). Universidad Nacional. Heredia, Costa Rica.

*Author for correspondence [mary.moreno.diazQuna.ac.cr]

\section{ABSTRACT}

The objective of this study was to quantify the economic benefits provided by the cluster of activities developed thanks to the existence of the Cocos Island National Park (CINP) and the ecosystem services it offers. The methodology consisted of employing cluster analysis complemented by a value chain approach identifying productive and non-productive activities related to the CINP and their interrelationships at the local, regional, national and international levels. The results determined that in 2019 the CINP allowed the generation of an income of US $\$ 19,682,466$, of which the most significant contribution was made at the national level (88\% of the total). The findings indicate the importance of protecting natural resources and marine species such as sharks (especially the hammerhead shark - Sphyrna lewini) from two potential threats, fishing and the effects of climate change, since the disappearance or decrease of such species could affect economic benefits.

Keywords: marine ecosystem, clusters, natural resources, ecosystem services

\section{RESUMEN}

El objetivo de la investigación era cuantificar los beneficios económicos que proveen el conglomerado de actividades que se desarrollan gracias a la existencia del Parque Nacional Isla del Coco (PNIC) y los servicios ecosistémicos que este ofrece. La metodología consistió en el enfoque de conglomerados complementado con la de cadenas de vaIor que permiten identificar las actividades productivas y no productivas relacionadas con el PNIC y sus interrelaciones a nivel local, regional, nacional e internacional. Los resultados determinaron que el PNIC, permitió generar en el 2019, un ingreso de $\$ 19.682 .466$, dónde el aporte realizado a nivel nacional resultó el más relevante ( $88 \%$ del total). Las conclusiones señalan la importancia de proteger los recursos naturales y especies marinas como el tiburón (especialmente el tiburón martillo - Sphyrna lewini), esto visto desde dos perspectivas, la pesca y el efecto del cambio climático, ya que, ante su desaparición o disminución se podrían afectar los beneficios económicos.

Palabras clave: ecosistema marino, conglomerados, recursos naturales, servicios ecosistémicos 


\section{INTRODUCTION}

The Cocos Island National Park (CINP) is one of Costa Rica's protected areas. It is internationally recognized for its wide biodiversity. Additionally, it is among the most recognized sites for the practice of recreational diving. Its features make it a unique, privileged place where schools of sharks and other species can be observed.

Activities are undertaken on the island by park rangers, researchers and volunteers 24 hours a day. The island has a tropical humid climate, with a temperature ranging from $24^{\circ} \mathrm{C}$ to $26^{\circ} \mathrm{C}$, and an average rainfall between 5,000 and $7,000 \mathrm{~mm}$ (Minae-SINAC-ACMC, 2007a). The CINP is one of the world's most privileged natural sites not only for its size but also due to its isolation and natural state.

The CINP has received a number of awards that have resulted in a greater commitment on the behalf of Costa Rica with respect to its conservation and protection. For example, it was named a World Heritage Site in 1997 by UNESCO, also being selected as a candidate for the "Seven Wonders of the World" contest. It was included on the Ramsar Convention List of Wetlands of International Importance (Ramsar, 2011). Additionally, the Costa Rican government declared it a Historic Heritage site in 2002 (ICOMOS Costa Rica, 2010).

It is located in the Pacific Ocean and belongs to the Republic of Costa Rica, which declared it a national park. It is located $535 \mathrm{~km}$ from Cabo Blanco at the southern tip of Costa Rica's Nicoya Peninsula. Its coordinates are $05^{\circ} 31^{\prime} \mathrm{N}-87^{\circ} 04^{\prime} \mathrm{W} / 5.517,-87.06$. Its land area is 23.85 $\mathrm{km} 2$, measuring $7.6 \mathrm{~km}$ long and $44 \mathrm{~km}$ wide, with it being roughly rectangular in shape (FAICO, 2011).

Economic activities in this marine space are limited so as to provide greater protection to the species in the area, however, tourism is allowed (as regulated by SINAC) since its impact on marine resources is minimal. The diversity of the park attracts on average 1,916 tourists, engaged in diving year round. Traditionally national parks are seen as a cost, but in fact they should be seen as investments that generate benefits. The objective of this study was therefore to approximate the economic benefits provided by the existence of the CINP due to the cluster of ecosystem activities and services that arise from its existence. In addition, analysis was made of the effect of climate change on the park and its economic income.

\section{MATERIAL AND METHODS}

\section{Methodological framework}

Ecosystems provide a number of services that are vital to the survival of both the ecosystem itself and the surrounding communities, including on regional, national and international levels. These ecosystem services, as defined by Millennium Ecosystem Assessment (MEA), are classified into four groups according to Armenteras and Morales (2010):

- Provision services: These are obtained directly from ecosystems, such as water and forest products.

- Regulatory services: These are achieved through ecological processes, for example, climate and disease control, among others.

- Cultural services: These benefits are not material, but rather include cultural, psychological and recreational benefits.

- Support services: These are required for the production of services belonging to the above categories, such as nutrient recycling.

However, as of 2017 the Multidisciplinary Expert Panel (MEP) in conjunction with the Intergovernmental Science-Policy Platform on Biodiversity and Ecosystem Services (IPBES) created a new conceptual framework that classifies ecosystem services into three groups: regulatory, material and non-material contributions. While this classification seems to differ from the previous one, the categories considered within each are very similar to those detailed by the MEA.

To evaluate these ecosystem services, the concept of Total Economic Value (TEV) is used. This is divided into use values and non-use values, which are calculated using valuation methodologies. As indicated by Moreno:

One way of classifying the different methods is to group them into direct, indirect, contingent valuation, variable valuation and macroeconomic models. Direct methods are based on the values observed directly in the market (prices, costs) to obtain the value of the change in the 
quantity/quality of a natural resource. Indirect methods use indirect market values arrived at through the market for goods related to the environmental good that meet certain conditions (2015, pp. 49-50).

The above allows ordering the methodologies according to individual preferences, that is, making a selection between the revealed preference and stated preference methods. For the present study the first method was used, which consists of:

Estimating the value that individuals give the Natural Resource (NR) and/or ecosystem service (ES) and analyzing the behavior of these in real markets with respect to the NR and/or ES, that is, collecting data on the choices made by individuals (Mogas, 2004, p.15).

National parks provide a number of benefits that can be considered as external, which have an impact on different areas of the territory. The park services are used by companies, individuals and organizations that work to preserve these contributions. To quantify these benefits, there are methodologies such as the cluster method explained below.

\section{The methodology applied}

The existence of the natural resources and the ecosystem services that these provide allow the development of activities that in turn elicit another series of related activities, so expanding the benefits generated. This approach is known as the cluster approach. This is identified as:

The tool suitable for the identification of productive activities (including research projects in or related to parks) and reproductive activities (in the social sense, including different levels and degrees of recreation).

This makes it possible to attribute as contributions of NPs the emergence and consolidation of these socioeconomic activities in order to estimate their benefits in terms of employment and income per visit, among others, both through numerical calculations and through qualitative indications (Furst et al., 2004, p.172).
The different activities generate a chain affecting different links in the country and even abroad, so generating economic and social income. The existence of the CINP has resulted in four groups of activities that form clusters: management, research, leisure and the promotion of wellbeing, as well as economic activities. This study was carried out using this methodology to approximate the benefits generated by each of the categories.

\section{Specific methodology}

For the analysis performed, a series of tools were implemented such as surveys of tourists, CINP staff, volunteers and researchers. In addition, interviews were made of the staff of tour operators, hotels, shipping companies, travel agencies, organizations and transport providers.

To determine the size of the sample of tourists to be interviewed, the average annual visit rate to the CINP was taken in account, this being 1,916 people. Based on this information, the following statistical formula was used ${ }^{1}$ :

$$
n=Z_{a}^{2} \frac{N * p * q}{i^{2}(N-1)+Z_{a}^{2} * p * q}
$$

The result indicated that the sample to be employed was 320 people, however, the fieldwork undertaken was able to obtain 371 surveys. For this purpose, three trips were made to the park in November-December 2018, September 2019, and October 2019. In this process, the company Fiesta Tours collaborated with transport and the facilitation of contact with tourists returning to San José during the months of October and November of 2019. In this time 16 tours were made together with the transport company. In addition, relevant information was collected through research centers, foundations and NGOs that in one way or another support the management of the Cocos Island $\mathrm{Na}$ tional Park. Contact was thus established with representatives of six organizations via telephone interviews.

Once the information was collected, it was processed and analyzed. The components forming part of the cluster of

\footnotetext{
${ }^{1} \mathrm{n}$ : is the sample size (number of surveys to be performed).

$\mathrm{N}$ : is the size of the population or universe (total number of potential respondents).

7: $5 \%$ margin of error, maximum error.

$\mathrm{Z} \frac{2}{2}$ : value corresponding to the Gaussian distribution for 1.960. This depends on the confidence level that is assigned.

1-D: $95 \%$ confidence level.
} 
activities developed in the CINP were thus identified, as were the production chains. Quantification of the benefits obtained by the existence of the CINP on a national and international level was carried out for 2019.

\section{RESULTS}

In the analysis of the clusters, four main axes were identified: leisure and the promotion of well-being; research and education; management; and economic activities. On the other hand, although the CINP provides several ecosystem services, the one that is most related to the approximation of the benefits generated by its existence is that of cultural services, from two perspectives: firstly, due to its scenic beauty and the promotion of leisure and well-being; and, secondly, due to the possibility of undertaking ecotourism focusing on marine species. The above generates the development of the four clusters mentioned above, which are discussed in more detail below.

\section{Leisure and the promotion of well-being}

This refers to the non-quantifiable benefits that the CINP extends to visitors, consisting of the experiences that tourists enjoy when they are there. These depend on the ecosystem services provided by the island's natural resources. Leisure and the promotion of well-being are activities that are carried out voluntarily as mechanisms to generate physical and psychological well-being, appreciating nature and natural diversity.

In the CINP, tourists can enjoy a variety of activities based on the recognized park attractions. The ecosystem services in this case are cultural, derived from scenic beauty and the conservation of biodiversity and marine species. Similarly, the park boasts rich biodiversity, scenic and spiritual beauty, invaluable contributions that constitute the key resources of the place, attracting thousands of visitors from all over the world who have the pleasure of enjoying the benefits mentioned above that arise from the CINP's spectacular natural endowments. The main activities are hiking along walking trails, observing species on the land and in the sea, diving in the coral reef and alongside sharks, snorkeling and kayaking. In this case, the cultural or non-material ecosystem service is represented.

\section{Research and education}

In this area, information was collected relevant to the de- velopment of academic and scientific activities carried out in the CINP by researchers, biologists and students, among others. In this case, the Cocos Marine Conservation Area (ACMC for the initials in Spanish), within which the CINP is located, provided 18 research permits during 2018, with this being 8 more permits than in 2017. However, no information is held on the financial resources that said research requires for its development. For the purposes of this document, investment in research and education is considered to be that carried out by two organizations that explicitly state that their main work is the development of scientific research. Thus, the estimated amount for this item was US $\$ 690,821.66$.

\section{Management}

The National System of Conservation Areas (SINAC for the initials in Spanish) and the ACMC are the entities responsible for the management of the CINP. According to records of individual visitation provided by the ACMC, in 2018 3,086 people entered the CINP. Of these 2,173 paid the entrance fee to the park and 913 were exonerated. The revenue received by the park comes from park entrance fees, and diving, docking, filming, snorkeling and submarine vessel access fees. The annual remuneration of the CINP was US $\$ 808,335$ (495,040,520 Costa Rican colones) and US $\$ 846,483$ (518,403,515 Costa Rican colones) for the years 2017 and 2018 respectively, representing an annual increase of $4.72 \%$.

On considering the annual variation, significant growth is observed for submarine vessel access (41\%), diving (5.93\%) and park entrance fees (4.43\%). In contrast, there was a decrease in activities related to filming (46.82\%), snorkeling (36.31\%) and docking fees (5.92\%). It can also be observed that the items related to entrance fees (70.95\%) and diving (26.29\%) represent the most important activities in terms of income generation, since both activities represent $97.24 \%$ of the contribution estimated for the CINP.

The CINP has made a set of agreements with and received collaborations from national and international foundations and organizations with the objective of promoting state management tasks in the park and its adjacent waters. Through fieldwork and direct communication with support organizations, it was estimated that the organizations' annual contribution to national development was US\$2,720,000 in 2018. 


\section{Economic Activities}

The main activity that takes place in the Cocos Island $\mathrm{Na}$ tional Park is tourism, however for this to be undertaken in the best fashion, other activities are necessary. Together these make up a production chain, which includes tour operators, hotels, restaurants, supermarkets and transportation, among others. Their contributions will be expanded upon in the following sections.

\section{Tourism and related activities}

The CINP receives a large number of visitors despite the difficulties of access. Nonetheless these are limited to tourists, researchers, volunteers and officials, SINAC employees and those of other public institutions. There has been a daily register of visitors to the island kept approximately since 1992, information that can be seen in Figure 1.

Figure 1. Cocos Island National Park annual visitation 1992-2018

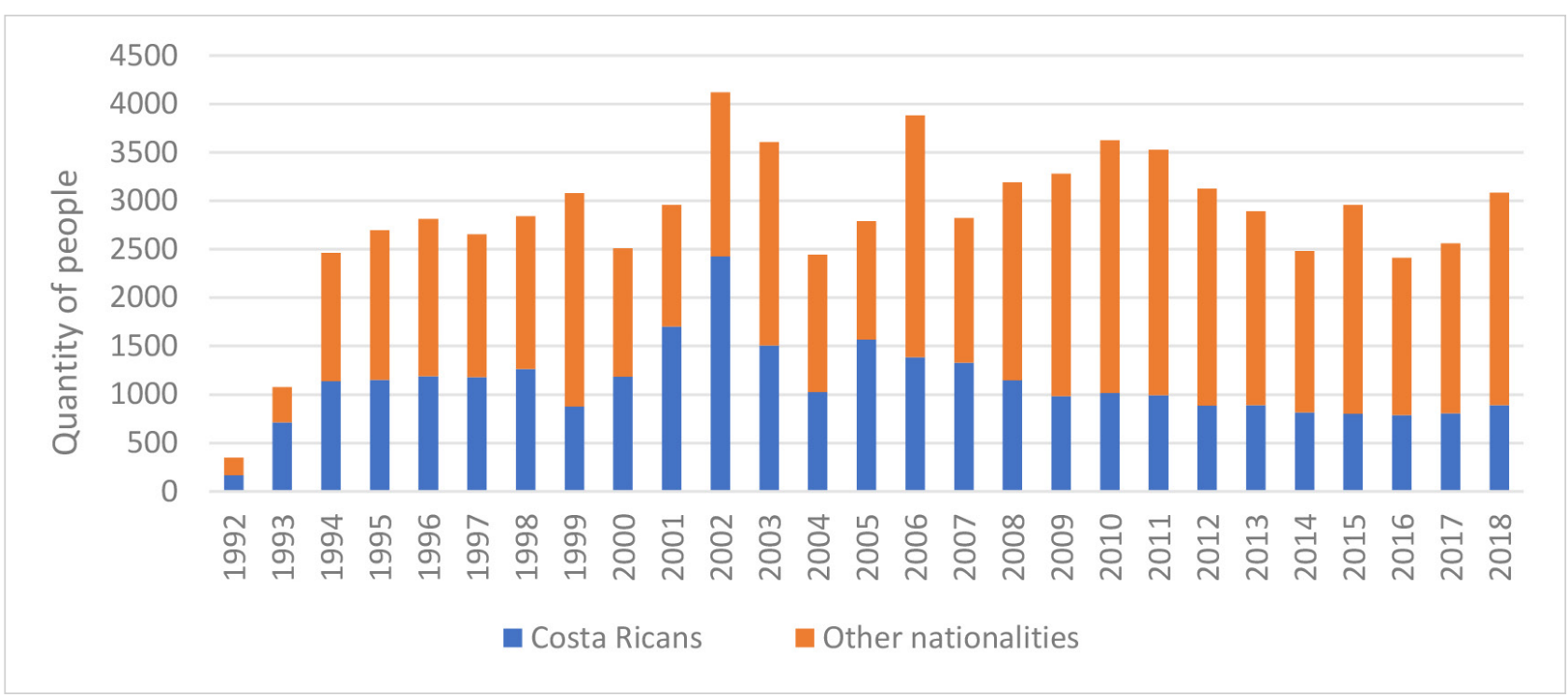

Note. The significant changes representing decreases in visitation are the result of global crises (1997, 2000, 2003, 2007) and the El Niño phenomenon. Own production based on data from MINAE-SINAC-ACMC (2007b) and ACMC 2016-2018b.

The data indicate that the year with the lowest visitation was 1992, when only 347 people were registered. Meanwhile, the highest visitation report was 4,121 people in 2002. GraduaIly the figures have come to stabilize at an average of 2,824 tourists per year. However, when considering only non-exonerated visitation, that is, people whose purpose is tourism and not research or other activities, the average is 1,916 tourists annually. From 1992 to 2018, the visitation growth rate was $638 \%$, representing a considerable increase.

\section{Visitation profile and average expenditure}

The fieldwork results indicate that $66.31 \%$ of the visitors are men and $33.15 \%$ are women. With regard to natio- nality, it is possible to observe that visitors come from a variety of countries and each of the continents with the exception of Antarctica. Included among the countries from which visitors to the CINP originate are the United States (14\%), Germany (12\%), France (9\%), Spain (6\%) and Costa Rica (6\%). $94 \%$ are foreigners and $6 \%$ are Costa Rican. However, when reviewed by region, Europe (56\%) is the continent from which most visitors come to the island, followed by America and the Caribbean (29\%), Asia (14\%), Africa (0.3\%) and Oceania (1\%).

Of the interviewees, $88 \%$ had previous knowledge of Cocos Island, 10\% hadn't heard of the island until the moment of planning the trip, while the remaining $2 \%$ did 
not respond to this question. Regarding the first group, the main means by which they obtained information was through recommendations from friends, the internet, and television, among others. It was determined that tourists perform between 3 and 4 activities during their stay in the CINP. 98\% go diving to observe sharks, $31 \%$ hike on the island trails, and 3\% go snorkeling, while the remaining $14 \%$ made no indications respecting this question.
In order to discover the importance of the natural resources to tourists, these were asked if their visit was specificaIly related to any of the island's specific marine or coastal resources. Regarding this question, $56 \%$ indicated that this was the case, $40 \%$ said no and $4 \%$ did not respond. Those who answered in the affirmative indicated that the reasons why they mainly visited the park were for shark watching, diving, and the marine ecosystem, among others. Figure 2 shows each of the percentages of these.

Figure 2. Reasons for visiting the CINP

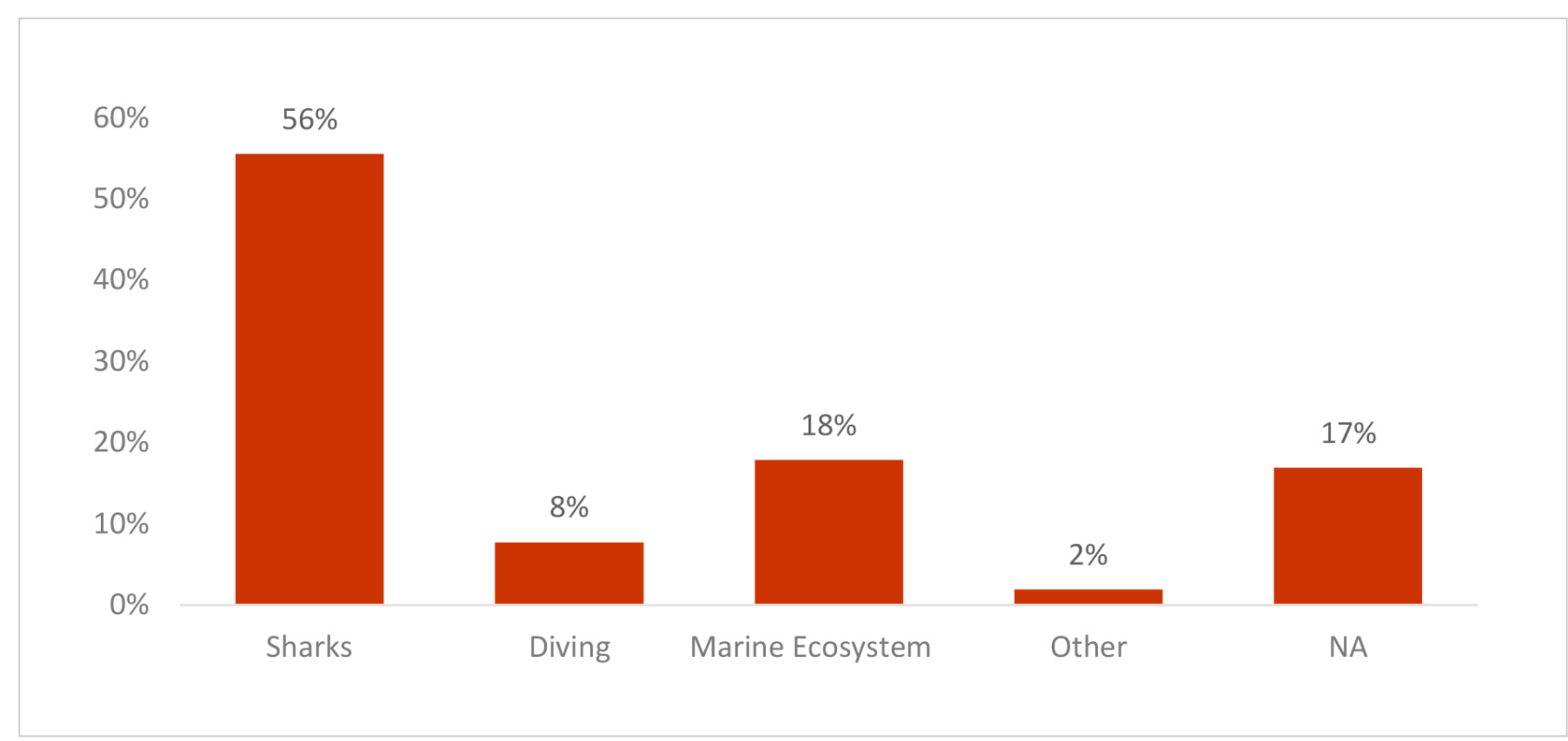

Note. Own production based on surveys, 2019

In relation to the previous question, survey respondents were asked if they would refrain from visiting the island in the event that the resource that drew them there were to decrease or disappear. $67 \%$ of the people answered in the affirmative, while $24 \%$ said no, and $9 \%$ made no response.

This information is of paramount importance, given that if the park resources are not properly conserved, the economic benefits it brings could decrease since there are tourists who have visited the island on more than one occasion. It should be added that most people have learned about the CINP thanks to the recommendations of friends and therefore a degradation of the ecosystem might not only cause tourists not to return to the island but may also cause them to refrain from recommending it to other acquaintances.

The average expenditure was estimated at US $\$ 6,820$, which takes into account expenditure on air tickets, land transport, accommodation, food, tour-operators, CINP entrance fees, daily diving fees, and purchases made in supermarkets and on souvenirs and equipment. As shown in Figure 3, two Asian nations face the highest costs, while Costa Ricans encounter the lowest costs. 
Figure 3. Average expenditure per country. In US dollars

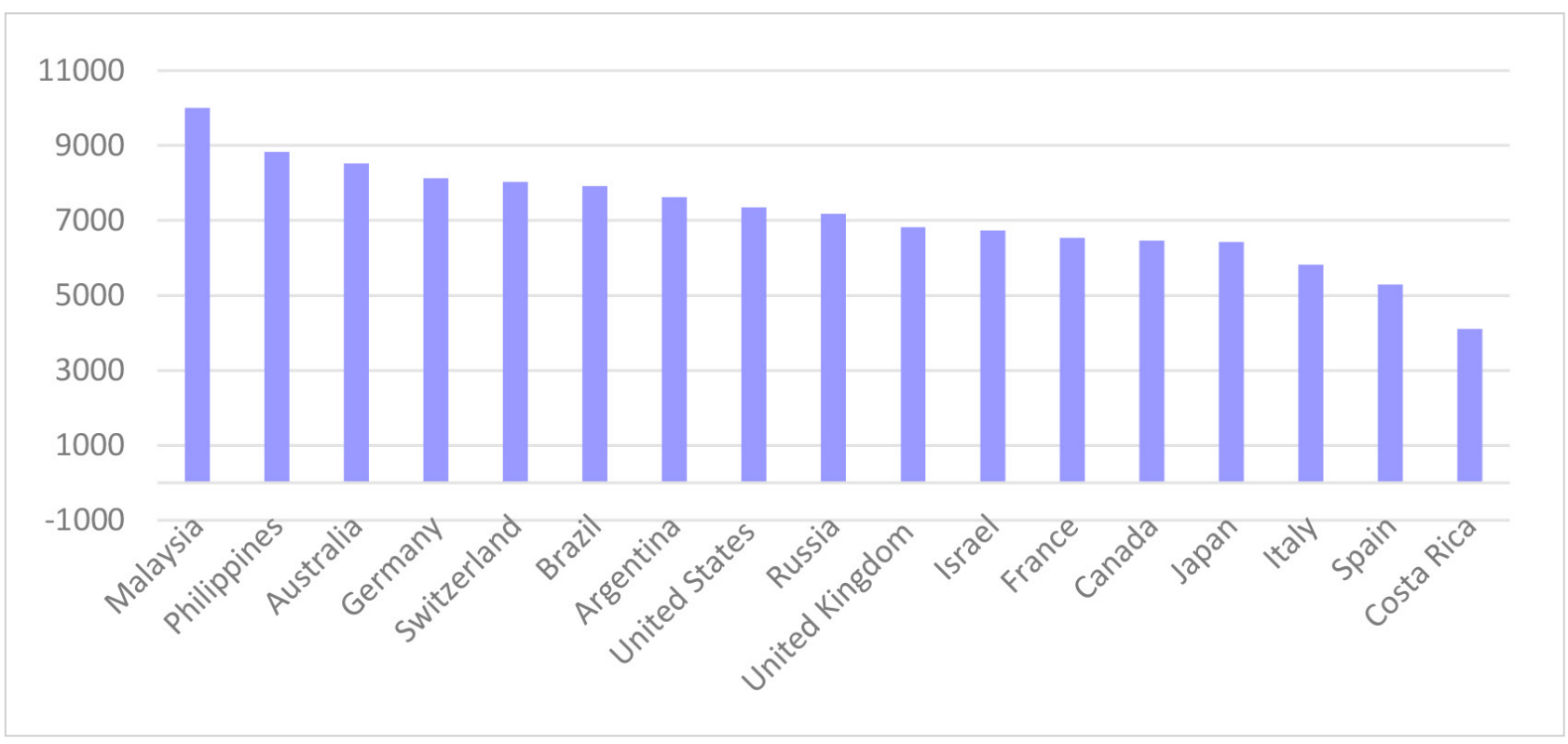

Note. Own production based on surveys, 2019

As indicated above, in order that tourism can be undertaken, other activities are necessary to provide tourists with a complete experience, as well as to allow their transfer to the boarding area and the acquisition of services and products.

\section{Supermarkets}

A stop is usually made at a supermarket in Puntarenas in which tourists can make final purchases before going aboard for their trip to the island. Among the most common products acquired are alcoholic beverages, personal hygiene products, sun cream and sun block, among others. According to an interview with the transportation manager, the average amount spent is US\$100. A quantification of income cannot be elaborated, however, due to the absence of data related to the percentage of tourists who make purchases.

\section{Tour Operators}

Currently two tourist companies are authorized by SINAC to carry out ecotourism and diving activities in the CINP. These are Inmobiliaria Renaciente SA/Okeanos Aggressor and Undersea Hunter Group. Both companies are foreign owned. In percentage terms, in 2019 the companies transported $70 \%$ of people who visited the CINP, while only $30 \%$ of people entered the park using private boats. It is worth noting that these companies generate an important percentage of the value chains produced by visits to the CINP, supporting the management carried out by state institutions in the park in different ways.

The information collected by this study indicates that the average expenditure of each tourist for their stay on a boat is US $\$ 5,163$. However, it should be noted that the qualification of benefits took into consideration that the price varies between boats and, in addition, one of the companies offers differentiated prices for Costa Ricans and foreigners. In this case, the total income raised is US $\$ 9,952,076$ annually.

\section{Hotels}

For logistical reasons, tour operator companies recommend customers stay in certain hotels that make up part of the circuit used by the company in charge of the transfer from San José to Puntarenas where the boats heading to the CINP are docked. In this regard, the suggested hoteIs are characterized as luxurious and comfortable, upholding high standards of quality and service. 
The data obtained in the fieldwork indicate that tourists on average spend US\$381 on accommodation, which implies that, per year, the hotels in mention receive an income of US $\$ 700,801$ for tourists traveling to Cocos Island.

\section{Transport}

To make the trip to the CINP, it is necessary to first arrive at the Puntarenas pier where the tour operators are located. Tourists therefore require transport in tour buses from San José to Puntarenas and vice versa. It is appropriate to indicate that this transport does not involve an additional cost for tourists, as it is included in the tour operator's fees. In addition, in some cases tourists hire taxis to travel in the vicinity of their hotels, or even tour buses to make other tours around the country. The data generated by the fieldwork indicates that on average each tourist spends US $\$ 162$ on land transport.

\section{Others: Restaurants, souvenirs and equipment}

On the way to Puntarenas, tour buses stop for approximately 45 minutes in restaurants where tourists can have breakfast, get snacks, buy souvenirs or use the sanitary services. Tourists usually bring their respective diving equipment with them, however, in some cases they have to make purchases to acquire some important pieces of equipment. On average, the expenditure under this heading is US $\$ 592$, which is to say US $\$ 1,134,568$ annually.

\section{CINP contributions at the national and international level}

As explained above, the existence of the Cocos Island National Park allows the development of tourist activity, however, the services provided by tour operators requires other activities to make the experience pleasant and complete. Therefore, a production chain is established with hotels, buses, restaurants and supermarkets that obtain profits thanks to the main activity.

The contributions of the CINP is perceived in different areas of the country. While the profits obtained at the level of supermarkets, restaurants, and from the purchase of equipment and souvenirs can be classified as contributions to the local and regional level, due to the dynamics of these services, it is difficult to calculate the profits these generate. For this reason, in this case the benefits were simply identified on the national and international levels.
In the systematization of the annual revenue generated on the national level, consideration was made of the resources provided by organizations whose purpose is research and other types of external support, the use of the park (income from entrance fees, diving, etc.), and the budget allocated for the administration of the ACMC. In addition, the activities outlined in the preceding paragraphs were taken into account in a disaggregated fashion, that is to say, the expenses that companies incur for utilities, maintenance, wages, fuel, among others, were deducted from income in order to observe the true value of each item to avoid double counting. Table 1 shows that the total annual contribution of the CINP is US\$17,245,294 $(\mathbb{1 0}, 561,363,370$ Costa Rican colones) on the national level. $43.33 \%$ of this amount corresponds to the benefits obtained by tour operators and private boats. The international contribution is also added. The bold line marks the differentiation between the different clusters identified: research, economic activities and management, respectively.

Regarding the international sphere, according to the information provided by the $\mathrm{ACMC}$ and the tour operators, the CINP is visited mostly by foreign tourists. This implies that they must travel by air from their countries to Costa Rica. While tour operators recommend flying to Costa Rica via direct flights from major cities, the selection of the type of flight depends on the tourists' preferences.

Due to the technology boom, there has been a shift away from travel agencies as a mechanism for the purchase of air tickets in favor of the major electronic pages and applications oriented towards the purchase of the same.

To compile the contribution of the CINP on the international level, the expenditure made by tourists acquiring air tickets according to their point of origin to arrive in Costa Rica to enjoy the CINP was taken into account. In this rubric, the data indicate that the average air ticket price is US $\$ 1,325$, which is to say that considering that $94 \%$ of tourists are foreigners, annually the contribution made by tourists traveling to Cocos Island is US $\$ 2,437,171$ ( $\$ 1,492,572,799$ Costa Rican colones).

When calculating the annual income generated at the national and international level by the activities developed around the CINP, it was estimated that for 2019 the approximate amount of the contribution was US\$19,682,466 (\$12,053,936,170 Costa Rican colones). 
Table 1. Systematization of annual income generated at the national and international level. (In US dollars, Costa Rican colones and percentages). 2019

\begin{tabular}{|c|c|c|c|c|c|c|}
\hline \multirow{3}{*}{$\begin{array}{l}\text { Scope-scale of } \\
\text { the contribution }\end{array}$} & \multirow{3}{*}{ Activities benefited } & \multirow{2}{*}{\multicolumn{4}{|c|}{$\begin{array}{l}\text { Type of contribution (good/service/ } \\
\text { externality) valued according to sources } \\
\text { Income }\end{array}$}} & \multirow{3}{*}{$\begin{array}{l}\text { \% of total } \\
\text { contribution }\end{array}$} \\
\hline & & & & & & \\
\hline & & \multicolumn{2}{|c|}{ Costa Rican colones } & \multicolumn{2}{|r|}{ US\$ } & \\
\hline \multirow{20}{*}{ NATIONAL } & Research & $\mathbb{4}$ & $423,073,000$ & $\$$ & 690,821 & $4.01 \%$ \\
\hline & $\begin{array}{l}\text { Tour operators and } \\
\text { private boats }\end{array}$ & & $4,576,264,403$ & $\$$ & $7,472,428$ & $43.33 \%$ \\
\hline & Accommodation & $\mathbb{A}$ & $429,185,084$ & $\$$ & 700,801 & $4.06 \%$ \\
\hline & Ground transportation & $\mathbb{A}$ & $182,488,146$ & $\$$ & 297,978 & $1.73 \%$ \\
\hline & $\begin{array}{l}\text { Others: Restaurants, } \\
\text { souvenirs and equipment }\end{array}$ & $\mathbb{4}$ & $694,832,134$ & $\$$ & $1,134,568$ & $6.58 \%$ \\
\hline & Basic Services & $\mathbb{4}$ & $63,504,962$ & $\$$ & 103,695 & $0.60 \%$ \\
\hline & Internet & $\mathbb{4}$ & $2,698,064$ & $\$$ & 4,405 & $0.03 \%$ \\
\hline & Cable TV & $\mathbb{\#}$ & 524,298 & $\$$ & 856 & $0.005 \%$ \\
\hline & Cleaning & $\mathbb{\#}$ & $19,293,765$ & $\$$ & 31,504 & $0.18 \%$ \\
\hline & Fuel & $\mathbb{4}$ & $557,230,218$ & $\$$ & 909,882 & $5.28 \%$ \\
\hline & Maintenance & $\mathbb{4}$ & $214,582,649$ & $\$$ & 350,384 & $2.03 \%$ \\
\hline & Beverages & $\mathbb{4}$ & $86,919,330$ & $\$$ & 141,927 & $0.82 \%$ \\
\hline & Food & $\mathbb{H}$ & $257,792,678$ & $\$$ & 420,940 & $2.44 \%$ \\
\hline & Other services & $\mathbb{\#}$ & $12,960,000$ & $\$$ & 21,161 & $0.12 \%$ \\
\hline & Salaries & $\mathbb{4}$ & $322,917,605$ & $\$$ & 527,281 & $3.06 \%$ \\
\hline & Fees for use of the CINP & $\mathbb{4}$ & $518,403,515$ & $\$$ & 846,483 & $4.91 \%$ \\
\hline & External support & $\not \mathbb{}$ & $1,665,782,400$ & $\$$ & $2,720,000$ & $15.77 \%$ \\
\hline & Direct employment & $\mathbb{4}$ & $419,015,361$ & $\$$ & 684.196 & $3.97 \%$ \\
\hline & ACMIC Administration & $\mathbb{4}$ & $113,895,751$ & $\$$ & 185,976 & $1.08 \%$ \\
\hline & National Total & & $10,561,363,370$ & $\$$ & $17,245,294$ & $100 \%$ \\
\hline INTERNATIONAL & International Total & & $1,492,572,799$ & $\$$ & $2,437,171$ & $100 \%$ \\
\hline
\end{tabular}

Note. Exchange rate used 612.42. Own production based on surveys and interviews 2019

In percentage terms, it is evident that the largest annual contribution is observed at the national level, since $88 \%$ of the contribution is reported in this area and only $12 \%$ corresponds to the contribution made at the international level.

\section{Possible effects of climate change on income from so- cio-economic activities}

The multiple activities carried out by humans at the industrial level, among others, have caused greenhouse gases that in turn cause a change in climatic conditions. In the case of the CINP, researchers and officials were consulted on the main effects observed on the island as a result of this phenomenon. In Figure 4, it can be seen that $41 \%$ of tourists indicated that an alteration exists in the relevant ecosystems, such as a decline in species. 
Figure 4. Main effects of climate change on the CINP according to officials and researchers

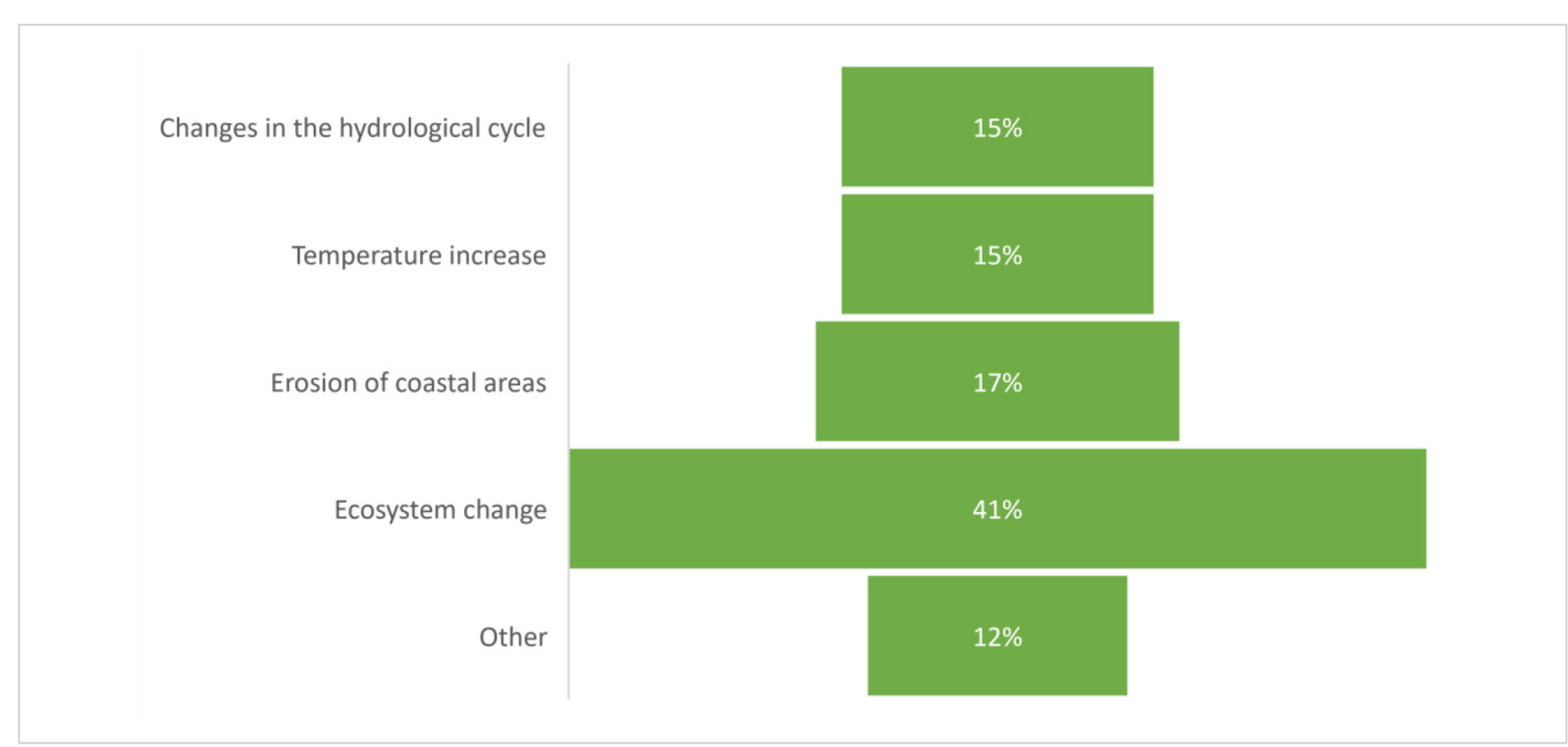

Note. Own elaboration based on survey data, 2019

In addition, McCauley (n.d.) considers that:

Species in the ocean appear to be much more sensitive to global warming as many are already close to the ceiling of the temperature range they can tolerate. This could explain why extinctions are currently occurring twice as much in the ocean as on the land (cited by Diario Veterinario, 2019).

Considering that $67 \%$ of tourists indicated previously that they would desist from visiting the park in the case of the disappearance or decline of the species of interest, it is possible to assert that an increase in the effects of climate change could lead to a decrease in economic income by around US\$13 million due to reduced visitation.

Due to the global nature of climate change, this determination becomes a complex challenge, however, recognizing where the main impacts occur can help the authorities responsible for managing this area know where they should concentrate their efforts, and thus remediate ecosystems and increase resistance to the impacts of climate change.

\section{DISCUSSION AND CONCLUSIONS}

The tourism cluster around the CINP represents a consolidated structure of activities and institutions oriented within the framework of ecotourism, in which ecosystem services are interconnected with the enjoyment of peoples' leisure. As stated by Moreno et al:

The cluster-chain methodology, which, although not considered as a valuation methodology as such, in its development uses instruments typical of ecosystem services valuation processes such as revealed preferences and market prices to approximate the value to society of the existence of national parks through their ecosystem services such as scenic beauty and ecotourism (2019, p.19).

Considering the above, this work was developed based on clusters as networks of public and private organizations and companies that generate contributions at the national and international level. On this point, it is necessary to indicate that, while there is clarity about the contribution 
obtained at the local level, it was not possible to obtain records or data that would allow the calculation of an appreciation of monetary value at this level, so the research focused on the contributions of the links on the national and international level when considering the contribution of the CINP.

In terms of the generation of the economic contribution at the national level, the tourism cluster generated US\$17,245,294 (\$10,561,363,370) in 2019. On the other hand, at an international level the estimated contribution of the CINP was US $\$ 2,437,171(\mathbb{1}, 492,572,799)$.

Taking into account the previously discussed information, it is estimated that the tourism cluster around the CINP generated in aggregate approximately US $\$ 19,682,466$ $(\mathbb{1} 12,053,936,170)$, of which $88 \%$ corresponds to the contribution obtained on a national level while the remaining $12 \%$ represents the international level.

At the national level, the driving force of the economic axis for the tourism cluster around the CINP are the tour operators, given that these are the economic agents that attract tourists to make the journey to Cocos Island, representing the connection with the other direct and indirect links.

Another key element with regard to the driving link is its orientation towards a niche market of foreign tourists characterized by a high level of purchasing power required for the development of a specialized activity such as diving, the cost of the tourism package, and a particular taste for conservation and the protection of the environment. In fact, specifically during the year 2019, of the tourists interviewed who traveled to the island, $94 \%$ were foreigners while only $6 \%$ were Costa Rican locals.

As the main recommendation, at an economic level the importance of shark species for the development of tourism is evident. The observation of sharks and their habitats is the main reason why tourists travel from abroad to Costa Rica. The data obtained shows that live sharks provide a profit of US $\$ 1,522,596$ annually, demonstrating that their protection is essential to prevent the different populations from continuing to decline. Given that a significant group of the respondents indicated that they would desist from visiting the island in the case of the disappearance of sharks, so representing the equivalent of 1284 fewer visi- tors per year, this would have a significant direct impact on benefits to the park and the economy of the country favored by this type of tourism (hotels, transport, restaurants and tour operators, among others).

In addition, taking into account that most tourists (82\%) report discovering the existence of the park through friends, this would mean that visiting the park would not be recommended in case of a decrease in the target species for which visitors come, which would cause a decrease in people who would be prepared to visit the park.

Sharks are mainly affected by fishing. Although there are regulations prohibiting this within the CINP, this is carried out in surrounding areas that are also visited by sharks and other marine species. In this way, increased surveillance and resources for this purpose are indispensable for true conservation. In Costa Rica, the price of shark meat is extremely low at less than US\$2 $(\mathbb{1} 1,015)$ per kilo, such that there exists neither economic nor environmental justifications to fish for a species that generates more benefits by remaining alive. Indeed, the economic benefits of a sector should never depend on the detriment of natural resources, which is why it is important to promote ecotourism and restrict the capturing of fish in sites used for recreation.

\section{ACKNOWLEDGMENTS}

We extend our sincere thanks to the Amigos Isla del Coco Foundation (FAICO for the initials in Spanish) for its support in the undertaking and financing of the research.

We wish to thank the technical supervision team: MINAE: Silvia Matamoros and Damián Martínez; ACMC: Gina Cuza, Esteban Herrera and Geiner Golfín; FAICO: Alejandra Villalobos and Andrea Montero for the feedback made on the drafts and final version of the study that gave rise to this article.

We thank SINAC and all the public and private institutions that supported us in undertaking this research.

\section{BIBLIOGRAPHY}

Área de Conservación Marina Cocos (ACMC). 2016. Visitación al PNIC 2016 [Visitation to the CINP 2016]. Cocos Island National Park - Costa Rica. 
Área de Conservación Marina Cocos (ACMC). 2017. Visitación al PNIC 2017 [Visitation to the CINP 2017]. Cocos Island National Park - Costa Rica.

Área de Conservación Marina Cocos (ACMC). 2018a. Consolidado de ingresos ACMC 2018 [Consolidated income statement ACMC 2018], Cocos Island National Park - Costa Rica.

Área de Conservación Marina Cocos (ACMC). 2018b. Visitación al PNIC 2018 [Visitation to the CINP 2018]. Cocos Island National Park - Costa Rica.

Área de Conservación Marina Cocos (ACMC). 2019. Información general del ACMC [ACMC General information]. Retrieved April 30, 2019, Isla del Coco: http://www.isladelcoco.go.cr

Armenteras, D. \& Morales, M. 2010. Manual de capacitación para EAI [Training Manual for EAl]. Aplicación del enfoque ecosistémico en las Evaluaciones Ambientales Integrales [Application of the ecosystem approach in comprehensive environmental assessments] (EAI). Vol. 2. United Nations Environment Program (UNEP). https://wedocs.unep.org/ bitstream/handle/20.500.11822/11212/Module-10-ecosystem-spanish.pdf?sequence $=2$ \&is Allowed=y

Diario Veterinario. 2019. Los animales marinos son más vulnerables al cambio climático [Marine animals are more vulnerable to climate change]. Article. http://www.diarioveterinario.com/textodiario/mostrar/1403486/animales-marinos-vulnerables-cambio-climatico

FAICO. 2011. Fundación Amigos de La Isla del Coco: http: www.cocoisland.org

Fürst, E., M.L. Moreno, D. Garcia \& E. Zamora. 2004. Desarrollo y conservación en interacción: ¿cómo y en cuánto se benefician la economía y la comunidad de las áreas silvestres protegidas en Costa Rica? [Development and conservation in interaction: How and how much do the economy and community benefit from protected wilderness areas in Costa Rica?] InBIO \& CINPE, Heredia, Costa Rica. www.inbio.ac.cr/otus/pdf/PNRB.pdf).
ICOMOS. 2010. Sitios de patrimonio nacional [National heritage sites]. Retrieved on April 05, 2011, from ICOMOS Costa Rica: http://www.icomoscr.org

Intergovernmental Science-Policy Platform on Biodiversity and Ecosystem Services 2017. Update on the classification of nature's contributions to people by the IPBES. Pp. 1-8. https://www.ipbes. net/system/tdf/downloads/pdf/ipbes5inf24.pdf?file=1\&type=node \&id $=534$

MINAE-SINAC-ACMIC. 2007a. Plan de Manejo del Parque Nacional Isla del Coco [Cocos Island National Park Management Plan]. Technical Paper. San José, Costa Rica. 122 pp. http://www.isladelcoco.go.cr/ attachments/079_Plan\%20de\%20Manejo\%20 PNIC.pdf

MINAE-SINAC-ACMIC. 2007b. Plan de Uso Público del Parque Nacional Isla del Coco [Plan for public use of Cocos Island National Park]. San José, Costa Rica.

Mogas, I. 2004. Métodos de preferencias declaradas y reveladas en la Valoración de impactos ambientales [Methods of stated and revealed preferences in the assessment of environmental impacts]. Ekonomías No. 57. Third quarter. https://dialnet.unirioja.es/ descarga/articulo/1373268.pdf

Moreno, M. L et al. 2012. Diagnóstico Socioeconómico Área de Conservación Marina Isla del Coco [Socio-economic diagnosis Cocos Island Marine Conservation Area]. ONE, CINPE, SINAC. Heredia, Costa Rica.

Moreno, M. L. 2015. Valoración de los efectos socioeconómicos y los recursos naturales en el contexto de la variabilidad climática en zonas costeras de Costa Rica [Assessment of socio-economic effects and natural resources in the context of climate variability in coastal areas of Costa Rica]. [Thesis to opt for the doctoral degree, Technological Institute of Costa Rica, Universidad Nacional, Universidad Estatal a Distancia]. Repositorio TEC. https://repositoriotec. tec.ac.cr/bitstream/handle/2238/9230/valoracion_efectos_socioeconomico_recursos_naturales_costas_cr.pdf?sequence $=1$ \&isAllowed $=\mathrm{y}$ 
Moreno, M. L., Hidalgo, H., Alfaro, E. 2019. Cambio climático y su posible efecto sobre los servicios ecosistémicos en dos parques nacionales de Costa Rica [Climate change and its possible effect on ecosystem services in two national parks of Costa Rica]. Revista Iberoamericana de Economía Ecológica. Vol. 30, No. 1: 16-38. https://ddd.uab.cat/pub/revibec/revibec_a2019v30/revibec_a2019v30p16.pdf

Ramsar. 2011. Ramsar Sites in order of addition to the
Ramsar List of Wetlands of International Importance. http://www.ramsar.org

SINAC (Sistema Nacional de Áreas de Conservación, CR). 2016. Propuesta de actualización del Plan General de Manejo del Parque Nacional Isla del Coco 2017-2026 [Proposal to update the General Management Plan of Cocos Island National Park 20172026]. Eds. H. Acevedo, V. Obando and Y. Villalobos. San José, Costa Rica. 